county, and in $1862,3,400$ by one house. The value of hogs in 1862 was $\$ 78,432$; of cattle, $\$ 174,097$; and of horses and mules, $\$ 313,747$. This year we produced 51,913 pounds of honey; 239,398 pounds of butter, and 25,600 pounds of tobacco.

In 1851, 635 of our population lived in villages, as follows : In Bloomfield, 348 ; in Drakeville, 139 ; in Troy, 101; in Dover, (now Stringtown,) 32 ; in Pleasantview, (commonly called Noseville,) 8; in Richmond, (now no more,) 6. That year Mr. McAtee was our County Assessor, and as there was some doubt as to whether there was a greater number of Veatches or Evanses in the county, he kept a list of each. The Evanses came out ahead-there being 101 of that name.

\title{
OHAPTER IV.
}

\section{CHURCHES, ETC.}

The Rev. L. W. Rankin, in 1841, organized near Troy, a New School Presbyterian Church, which was the first religious organization in the county; the Rev. Thomas Kirkpatrick of the Methodist Episcopal Church, had preaching in that neighborhood, however, before Mr. Rankin. And but a short time afterwards the Rev. Mr. Post, a Missionary Baptist, organized a church in the neighborhood of Stringtown. I think, in the year 1844, the first church was organized at or near Bloomfield, although christians did not neglect to assemble themselves together on the Lord's day for religious instruction. During that year the Conference of the Methodist Episcopal Church sent a Minister, (Rev. Mr. New,) to the county seat, under whose stewardship a church was organized. He labored with us for one year. The next year Rev. Hugh Gibson of the same church was sent here and remained two years. Mr. Gibson was much respected by all, both in and out of the church, and was accounted a good man and a christian. He resided, as did Mr. New also, in a small $\log$ cabin, then standing immediately west of the present M. E, 
Church building, and which was removed only two or three years since.

During the time Mr. Gibson preached for us, a Sabbath School was organized, which met each Sabbath at the old log Court House. Among the principal persons in this organization, besides the preacher, were Harvey Sloan, (now deceased,) Jonathan Wheeler, Lewis Rominger, the writer of these sketches, and others. About this time, in the vicinity of Troy and along the Van Buren County line, there were four several religious organizations - the Presbyterians, Methodists, Christians and Mormons. And as we are informed, at times there was no little religious excitement. The church members were very devoted, and watched the advancement of other churches with a jealous eye. During warm weather meetings were held in the groves, and in winter at private houses. In those days people came a great way to meetingon foot, a horse-back, in wagons, carts and sleds-drawn by horses, mules and oxen! 'The third minister sent to Bloomfield was Rev. John Jay-one of the best fellows extant-always pleasant and agreeable. Mr. Jay resided in the same cabin his predecessors did, and the writer had the honor at that time of occupying an older one opposite. Mr. Jay remained here two years, and during his stay, the first temperance movement in our county, that we know of, was got up. A society on the old Washingtonian plan was organized, and many were induced to sign the pledge. The meetings were kept up weekly, until sometime after its organization, when it was finally swallowed up by the institution of the "Sons of Temperance." Rev. A. W. Johnson of the M. E. Churrh, was next sent here. He remained one year only, and was followed by Rev. R. H. Harrison, who also tarried but one year. Rev. Joel Arrington was assigned to us next, and remained here until his death, which was about one year from the time he came. Mr. Arrington was very popular with the people, and did much good.

Other churches were organized in the county previous to 
1850,-Methodist, Presbyterians, Baptist, Christians, \&c, but I am unable to give any very correct statement in regard to them, notwithstanding I have made much inquiry. As early as 1845 , Rev. D. Trullinger of the Christian church had been preaching in the vicinity of Drakeville, and I think had organized a chureh here. Since that time that church has prospered in that vicinity under the charge of Rev. Levi Fleming and others of that denomination. The date when the Christian and Missionary Baptist churches were organized in our town I am unable to give, neither ean I name the first who preached for either of them, or organized their respective churches. Both denominations, however, have good ehurch buildings, Sabbath schools and respectable membership. At one time the New School Presbyterians had an organization here, and Rev. Asa Martin preached for them for one year or more. The membership being small, Mr. Martin removed to West Grove to labor for the Society at that place, and the organization here was dissolved.

After the death of Mr. Arrinton, the Methodist Conferance sent Rev. David Dickinson to the county seat who remained here one year only, and during that time, I am satisfied, he was paid less for his labor than an ordinary hod-carrier's wages who labors but half his time! The present Meeting House belonging to that church was principally built during that year, although it had been undertaken before he came.

Dr. Dickinson was a good man, a christian, and entirely too modest to make a living by any business or profession which requires begging. He was followed by Rev. F. H. Cary, at this time one of our Representatives in the State legislature.

He filled the pulpit two years and was succeeded by the Rev. H. Clay Dean. Mr. Dean came to our place, and preached once, and disagreeing with some of the members of his church refused to remain, and Rev. F. W. Evans supplied his place. Mr. Evans also had trouble with his flock, and like his immediate predecessor failed to fill out his time. The following ministers of the Methodist Episcopal Churh have since 
that time been sent here in the following order: Rev. R. L. Rowley, Rev. A. Bussey, Rev. S. Hestwood, Rev. John Burgess, Rev. J. B. Hardy, Rev. Thomas Audus, Rev. G. W. Byrkit and Rev. R. B. Allender.

Since writing the foregoing, I have been placed under obligations to Rev, R. T. Peak, for a statement in regard to the Missionary Baptist. At present that denomination has eight organized societies in our county, with a membership of three hundred and ninety-nine. Five of these societies have neat and substantial meeting houses-three of which are 32 by 44 feet, and one is 22 by 50 feet.

Rev. E. Kinman is now the pastor of North Union Church, which was organized in 1841; Rev. John Furgeson is pastor of Chequest Union Church, organized in 1848 ; Rev. R. T. Peak is pastor of Bloomfield Church, organized in 1849. Since the organization of this church it has had the following pastors: Rev. Chesley Woodward, Rev. A. G. Doom, Rev. D. H. Paul, Rev. G. J. Line, Rev. E. Kinman and Mr. Peak. Rev. A. P. Berry is pastor of Zion Church, organized in 1850; Rev. J. Newland is pastor of North Fabius-time of organization not known; Rev. B. Ogle is pastor of New Hope, organized in 1852 ; Rev. J. W. Osborn is pastor of Liberty Church, organized in 1857; and Pulaski Church, organized in 1858 , has no pastor at this time.

Charitable and Secret Institurtons. - In the year 1847 or ' 48 , the writer and other citizens of this place organized a temperance society on the old Washingtonian plan, which met once a week in the Court House, where songs were sung, speeches and lectures heard, and the pledge signed by many of our citizens.

In February, 1846, the "ancient and honorable" institution-Eclampus Vitus-was organized at our county seat, and for some time flourished above anything of the kind ever before or since tried in this meridian. Much of its success may be attributed to the energy and perseverance of its devotees and patrons, among whom we may name the first 
and best citizens of the county. Drs. Selman, Phelps and Findley, Judge Riggs and Hon. I. Kister, as well as all the more prominent citizens of the time, were ever ready at the altar of the order to render "aid and comfort" to brothers in distress, or strangers seeking light and knowledge through the mysteries of the ritual! The order of Eclampus Vitus went on "conquering and to conquer," until pretty much everybody had been "taken in."

In the summer of 1847 , Franklin Lodge, No. 14, A. F. and A. Mason, was instituted by the G. L. of the State, by appointing Hosea B. Horn, W. M.; Dr. Jno. J. Selman, S. W. ; and John W. Ellis, J. W. This institution and lodge has gone on gradually, and is now in good condition, and during its existence has at several times received the compliment of the G. L. for its correct work.

During the year 1849, "Father Matthew Division, No. 51, Sons of Temgerance," was instituted, and continued to do much good for three or four years, but finally yielded up the ghost, to be followed by the order of Good Templars.

"Bloomfield Lodge, No. 23, I. O. O. F.," was also instituted by the Grand Lodge, in the fall of 1849 , and from first to last has had within its folds many good and true men and Odd Fellows.

In March, 1850, Bloomfield Circle No. 1-117, B. U. (H. F.) C. A., by charter of the Supreme Circle at Philadelphia, was instituted, and continued to work until a few years since, when the members ceased to meet, it being too practical in its working to suit the tastes and inclinations of the western people.

In 1854 , the I. O. of G. T. was organized, and flourished wonderfully for a time, but finally failed; and to an outsider it would seem that no good whatever was accomplished by the organization.

The same year, Davis Lodge, No. 65, I. O. O. F., was instituted, and met with reasonable success, and was not wanting in offices of charity, but about the time of the breaking 11 
out of the rebellion, the two Odd Fellow Lodges of Bloomfield (No. 23 and No. 65) united under the name and number of the former.

In February, 1855, a secret political organization, popularly termed "Know Nothings," was instituted at the county seat. Its charter was issued from Davenport, and was signed by Judge Tuthill, as President of the Grand Council, and one DeFrame, as Secretary. The institution was put in operation here by Col. J. M. Shelley and George M. Huston, of Keokuk. This institution ran a rapid course.

In 1856, Bloomfield Encampment, No. 14, a higher grade of Odd Fellowship, was organized in our town, and I am told is now in good condition, and numbering in its membership some of our best citizens.

In the same year (1856), Prairie Gem Temple of Honor N. S., was instituted, and having lingered along some time, finally followed in the footsteps of all other temperance organizations of our place, and went under without leaving a sign to mark the place where it sunk!

The Masons also have a Chapter organization here, but I do not know when it was organized nor what its number is, although I have made some effort to obtain the information.

Although one after another of our temperance organizations have went down, all will admit that such organizations have been the means of doing much good in our midst-probably more good than all the other secret organizations put together. At the time the first temperance movement was set on foot, whisky was dealt out at every corner of our town, and drunkenness was respectable in the village and county. Through the agency of temperance organizations, all such sinks of hades have been effectually dried up in this region, and drinking and drunkenness have fallen into disrepute and become odious and disreputable. 
Copyright of Annals of Iowa is the property of State of Iowa, by \& through the State Historical Society of Iowa and its content may not be copied or emailed to multiple sites or posted to a listserv without the copyright holder's express written permission. However, users may print, download, or email articles for individual use. 